228

Received: October 27, 2017

Accepted: December 13, 2017
Macedonian Journal of Animal Science, Vol. 7, No. 1-2, pp. 7-11 (2017)

ISSN $1857-6907$

e-ISSN $1857-7709$

UDC: $636.39(497.7)$

Original scientific paper

\title{
CORRELATION BETWEEN CERTAIN EXTERIOR AND PRODUCTION TRAITS IN INDIGENOUS BALKAN GOAT IN MACEDONIA
}

\author{
Nikola Pacinovski ${ }^{1}$, Vladimir Djabirski ${ }^{2}$, Georgi Dimov ${ }^{3}$, Kocho Porchu $^{2}$, Elena Eftimova ${ }^{1}$, \\ Nedeljka Nikolova ${ }^{1}$, Natasha Mateva ${ }^{1}$, Bone Palashevski ${ }^{1}$, Goran. Trajkovski ${ }^{2}$ \\ ${ }^{1}$ Institute of Animal Science, "Ss Cyril and Methodius" University in Skopje, \\ Blvd. Ilinden 92A, 1000 Skopje, Republic of Macedonia \\ ${ }^{2}$ Faculty of Agricultural Sciences and Food, "Ss Cyril and Methodius" University in Skopje, \\ Blvd. Aleksandar Makedonski bb, 1000 Skopje, Republic of Macedonia \\ ${ }^{3}$ AgroBioInstitute, 8 Blvd. Dragan Tsankov, 1164 Sofia, Bulgaria \\ npacinovski@yahoo.com
}

\begin{abstract}
The purpose of this research was to determine the average values of certain exterior measures and production traits in goats of the indigenous Balkan breed in the Republic of Macedonia as well as to study their mutual correlation dependence. It was determined that the average body weight of the goats of Balkan breed is about $44 \mathrm{~kg}$, whereas the values of the other exterior measures were: height of withers $65.40 \mathrm{~cm}$, height of back $63.67 \mathrm{~cm}$, height of sacrum 65 $\mathrm{cm}$, body length $65 \mathrm{~cm}$, chest width $21.73 \mathrm{~cm}$, chest depth $25.23 \mathrm{~cm}$, size of chest $82.40 \mathrm{~cm}$, rump width $19.92 \mathrm{~cm}$, rump length $23.05 \mathrm{~cm}$. The average lactation was 166 litres. Regarding the strength of the correlation, the general conclusion is that there is a relatively weak correlation $(0.2 \leq \mathrm{R}<0.5)$ between most of the exterior measures. An average strong correlation $(0.5 \leq \mathrm{R}<0.8)$ was determined between the height of the sacrum and the height of withers and the height of the back, between the length of the body and body weight, as well as between the chest size and the width and length of rump. A strong correlation $(0.8 \leq \mathrm{R}<1)$ was determined between the height of withers and height of the back, as well as between the chest size and body weight. With the analysis of the correlative dependence of the lactation with the other exterior measures, it was determined that the lactation is not in correlation with most of the exterior measures, but there is an insignificant correlation $(0<R<0.2)$ with part of them (height of sacrum, chest size and length of rump).
\end{abstract}

Key words: indigenous Balkan goats; exterior measures; body weight; milk production; correlation

\section{КОРЕЛАЦИЈА ПОМЕЃУ ОДРЕДЕНИ НАДВОРЕШНИ ОСОБИНИ И ПРОИЗВОДНИ СВОЈСТВА КАЈ АВТОХТОНАТА БАЛКАНСКА КОЗА ВО МАКЕДОНИЈА}

Цел на овие испитувања беше да се утврдат просечните вредности на одредени надворешни особини и производни својства кај козите од автохтоната балканска раса во Република Македонија, како и проучување на нивната меѓусебна корелациона зависност. Беше утврдено дека просечната жива маса на козите од балканската раса изнесува околу $44 \mathrm{~kg}$, додека надворешните димензии изнесуваа: висина на гребенот 65,40 cm, висина на грбот 63,67 cm, висина на крстот $65 \mathrm{~cm}$, должина на трупот 64,95 cm, ширина на градите 21,73 cm, длабочина на градите $25,23 \mathrm{~cm}$, обем на градите $82,40 \mathrm{~cm}$, ширина на сапите $19,92 \mathrm{~cm}$, должина на сапите $23,05 \mathrm{~cm}$. Просечната лактациска млечност изнесуваше околу 166 литри. Во однос на јачината на корелацијата, генерален заклучок е дека повеќето надворешни димензии имаат главно релативно слаба меѓусебна корелација $(0,2 \leq \mathrm{R}<$ $0,5)$. Средно јака корелација $(0,5 \leq \mathrm{R}<0,8)$ беше утврдена помеѓу висината на крстот и висината на гребенот и висината на грбот, потоа помеѓу должината на телото и живата маса, како и помеѓу обемот на градите и ширината и должината на сапите. Јака корелација $(0,8 \leq \mathrm{R}<1)$ беше утврдена помеѓу висината на гребенот и висината на грбот, како и помеѓу обемот на градите и живата маса. Анализирајќ ја корелационата зависност на лактациската млечност од надворешните димензии, утврдено е дека со повеќето од нив таа не е во корелација, додека со мал дел (висината на крстот, обемот на градите и должината на сапите) е во незначителна корелација $(0<\mathrm{R}<0,2)$.

Клучни зборови: автохтона балканска коза; надворешни димензии; телесна маса; продукција на млеко; корелација 


\section{INTRODUCTION}

The population of Balkan goat in the Republic of Macedonia is about 38,378 goats, which represents almost half $(48 \%)$ of the total population $(79,664)$ in the Republic of Macedonia (Pacinovski et al., 2012). As an indigenous goat breed, Balkan goat is well adopted to the existing pasture resources, both in the lowlands and in the hilly-mountainous regions of the country (Kozarovski, 1998).

Bearing in mind that the milk from this ruminant has specific nutritional-dietary characteristics, the same has greater importance from year to year in the daily diet of people. The main reason for such is the extremely positive and health benefits of this nutrient on human health. Ten years ago there were almost no dairies involved in the purchase of goat milk, but today a significant number of dairy farmers purchase this type of milk as much as possible.

In this context, there is a tendency among the farmers to find variety of ways to increase the production of milk in their flocks. In this direction, although the selection is the slowest but is one of the most secure ways of improving the production traits in goats and therefore of milk. In domestic animals, even in goats, it has been scientifically proven that there are certain correlations between certain production and other traits. The main essence of this correlation is that the manifestation of an occurrence or trait, more or less, determines the appearance of another trait. By studying this correlations, it has been scientifically proven that the genetic and paragenetic factors influence on them.

The aim of these research was to determine the average values of certain exterior measures and production traits in goats of indigenous Balkan breed in the Republic of Macedonia, as well as to study their mutual correlation dependence.

\section{MATERIAL AND METHODS}

We used a flock of Balkan goats breed, located in the south-east part of Macedonia, during 2014 as basic experimental material. The measurements were realized on 242 goats in the age from the first to the seventh lactation (2-8 years) (Table 1).

A total of 9 exterior measures have been monitored: height of the withers, height of the back, height of the sacrum, body length, width of chest, depth of chest, chest circumference, width of the rump and length of the rump.
Table 1

The age range of goats

\begin{tabular}{|c|c|c|c|c|c|c|c|c|}
\hline \multirow{2}{*}{ Year } & \multicolumn{7}{|c|}{ Lactation } & \multirow{2}{*}{ Total } \\
\hline & I & II & III & IV & V & VI & VII & \\
\hline 2014 & 84 & 53 & 70 & 26 & 4 & 3 & 2 & 242 \\
\hline
\end{tabular}

Parallel to the exterior measures, the body weight of goats was measured in all tested goats. This measurement was carried out in May 2014. The following 8 exterior measures were measured using the Lydtin stick for small ruminants: height of the withers, height of the back, height of the sacrum, body length, width of chest, depth of chest, width of the rump and length of the rump, whereas the chest circumference was measured with measuring tape. Body weight was measured with an electronic scale (Taiwan Scale MFG CO., LTD, Indicator LD).

Based on the obtained results of the measurements, the average value for each exterior measure as well as the average body weight of goats has been calculated.

The standard A4 method was used for measurement of daily milk production per goat (morning and evening milk), in the interval from 28 to 34 days. The testing of milk started after the weaned of the kids (average 60 days age) and lasted until the moment of drying (end of October, i.e. middle of November). There were realized a total of 7 milk tests in 2014.

Mainly combined (barn-pasture) system of breeding was used on the farm, which means usage of the available vegetation during almost the entire year, whereas in a certain period of the year, especially in winter, goats were fed additionally with meadow hay (November - February) and concentrate (January - April). Kids stayed with their mothers depending on the purpose. Kids intended for slaughter, stayed with their mothers until they were sold for meat ( $2-2.5$ months age), whereas those intended for reproduction, stayed little longer, up to 3 months. The milking period started after the weaning of the kids.

The correlation between mentioned traits was calculated using package programs SPSS (SPSS, 1994), while strength of correlations was determined according to the Roemer-Orphal classification (Latinović, 1996).

The statistical significance of the effect considered was evaluated by means of the variance analysis at the level $\mathrm{P}<0.05$ and $\mathrm{P}<0.01$. The varia- 
tions between each mean value were also tested applying the T-test.

\section{RESULTS AND DISCUSSION}

The average values for all exterior measures and body weight are presented in Table 2 .

Table 2

Average values of certain exterior measures in Balkan goat breed in the Republic of Macedonia

\begin{tabular}{|c|c|c|c|c|c|}
\hline Exterior measure & Value & $\min$ & $\max$ & $\begin{array}{l}\text { Standard } \\
\text { deviat. } \\
(\mathrm{Sd})\end{array}$ & $\begin{array}{l}\text { Coeffic.. of } \\
\text { variation } \\
(\mathrm{Cv})\end{array}$ \\
\hline Height of withers, $\mathrm{cm}$ & 65.40 & 52 & 77 & 4.03 & 6.16 \\
\hline Height of back, cm & 63.67 & 50 & 75 & 4.18 & 6.57 \\
\hline Height of sacrum, $\mathrm{cm}$ & 65.04 & 60 & 76 & 5.48 & 8.43 \\
\hline Body length, cm & 64.95 & 45 & 82 & 5.17 & 7.96 \\
\hline Width of chest, cm & 21.73 & 14 & 33 & 3.88 & 17.86 \\
\hline Depth of chest, cm & 25.13 & 16 & 34 & 2.76 & 10.98 \\
\hline Chest circumference, $\mathrm{cm}$ & 82.40 & 64 & 94 & 5.05 & 6.13 \\
\hline Width of rump, cm & 19.92 & 14 & 24 & 1.55 & 7.78 \\
\hline Length of rump, $\mathrm{cm}$ & 23.05 & 18 & 26 & 1.55 & 6.72 \\
\hline Body weight, $\mathrm{kg}$ & 44.29 & 25 & 62 & 6.68 & 15.08 \\
\hline Milk yield, liters & 165.82 & 39 & 537 & 11.34 & 6.84 \\
\hline
\end{tabular}

According to the obtained results, the average body weight of Balkan goats is about $44 \mathrm{~kg}$, with a variation of $25 \mathrm{~kg}$ to $62 \mathrm{~kg}$, with coefficient of variation of 15.08. The values of the other exteriors measures are: height of the withers $65.40 \mathrm{~cm}$, height of the back $63.67 \mathrm{~cm}$, height of the sacrum $65 \mathrm{~cm}$, body length $65 \mathrm{~cm}$, width of the chest $21.73 \mathrm{~cm}$, depth of the chest $25.23 \mathrm{~cm}$, chest circumference is $82.40 \mathrm{~cm}$, the width of the rump is $19.92 \mathrm{~cm}$ and length of the rump is $23.05 \mathrm{~cm}$. The minimum and maximum values, and all of these exterior measures are within normal limits, without any extreme deviations, indicating standard and normal body development of the goats.

Milk yield in this population of goats is about 166 liters, with a variation of 39 to 537 liters. In this case it can be concluded that there is a great variation between the minimum and the maximum established lactation, which on the other hand creates the possibility for further selection in the direction of improving the annual milk production of this indigenous goat breed.

Compared with other studies of exterior measures in Balkan goats, it can be concluded that the results are quite similar.

Similar values for the height of the withers $(66.29 \mathrm{~cm})$ in Balkan goat in Serbia were determined by Memishi et al. (2002). The same authors determined higher values for some of the mentioned exteriors measures (body length $70.06 \mathrm{~cm}$, depth of the chest $29.88 \mathrm{~cm}$ ), whereas for others exterior measures they determined smaller values (width of the chest of $16.94 \mathrm{~cm}$, width of the rump of $17.47 \mathrm{~cm}$ ).

The abovementioned authors determined smaller value for the body weight $(38.55 \mathrm{~kg}) \mathrm{com}$ pared to the body weight measured in our tests $(44.29 \mathrm{~kg})$, which is probably due to the fact that the flock used in our tests is located in lowlands (better in food), whereas the flock in Serbia is located in the mountain part (poorer with pasture). This probably corresponds also with the statement of Kozarovski (1998), that there are two varieties of the Balkan goat in the Republic of Macedonia: Balkan goat located in the mountains, which is smaller, as well as Balkan goat located in lowlands, which is heavier and larger in size.

Considering that Memishi et al. (2002) determined these values in four adult goat categories (first to fourth lactation), they determined the lowest body weight in goats in the first lactation (30.93 $\mathrm{kg}$ ), whereas the highest body weight in the oldest, i.e. goats in the fourth lactation $(44.31 \mathrm{~kg})$. The same tendency of lower values among the younger goats, i.e. higher in the older goats was determined in the other exteriors measures. The general conclusion of these authors is that the Balkan goat is a latematuring breed, and that its growth ends in the fourth lactation or in the age of around 5 years.

The intensity of the correlation between the measured exterior measures, the annual lactation and body weight of Balkan goat and the established statistical significance is presented in Table 3.

When it comes to the correlative dependence between the exterior measures during these tests, a statistically significant correlation was determined, almost among all tested measures.

For example, the height of the withers has highly significant correlation with almost all other measures, with the exception of the width of the chest with which it is not correlated. It is the same with the height of the back and the height of the sacrum. 
Table 3

Phenotypic correlations between exterior measures, milk yield and body weight of Balkan goats in Macedonia

\begin{tabular}{|c|c|c|c|c|c|c|c|c|c|c|c|}
\hline Parameters & $\begin{array}{c}\text { Milk } \\
\text { yield } \\
\text { (liters) }\end{array}$ & $\begin{array}{l}\text { Body } \\
\text { weight } \\
(\mathrm{kg})\end{array}$ & $\begin{array}{l}\text { Height of } \\
\text { withers } \\
(\mathrm{cm})\end{array}$ & $\begin{array}{l}\text { Height } \\
\text { of back } \\
(\mathrm{cm})\end{array}$ & $\begin{array}{l}\text { Height } \\
\text { of sacrum } \\
\quad(\mathrm{cm})\end{array}$ & $\begin{array}{l}\text { Body } \\
\text { length } \\
(\mathrm{cm})\end{array}$ & $\begin{array}{l}\text { Width } \\
\text { of chest } \\
(\mathrm{cm})\end{array}$ & $\begin{array}{l}\text { Depth } \\
\text { of chest } \\
(\mathrm{cm})\end{array}$ & $\begin{array}{l}\text { Chest circ- } \\
\text { umference } \\
\quad(\mathrm{cm})\end{array}$ & $\begin{array}{l}\text { Width } \\
\text { of rump } \\
(\mathrm{cm})\end{array}$ & $\begin{array}{l}\text { Length } \\
\text { of rump } \\
\quad(\mathrm{cm})\end{array}$ \\
\hline Milk yield (liters) & 1 & $0.155^{*}$ & $-0.030^{\mathrm{ns}}$ & $-0.071^{\mathrm{ns}}$ & $-0.140 *$ & $0.059^{\mathrm{ns}}$ & $0.048^{\mathrm{ns}}$ & $0.123^{\mathrm{ns}}$ & $0.164^{*}$ & $0.082^{\mathrm{ns}}$ & $0.127 *$ \\
\hline Body weight (kg) & $0.155^{*}$ & 1 & $0.486 * *$ & $0.433 * *$ & $0.366 * *$ & $0.501 * *$ & $0.277 * *$ & $0.413 * *$ & $0.811^{* *}$ & $0.541 * *$ & $0.382 * *$ \\
\hline Height of withers $(\mathrm{cm})$ & $-0.030^{\mathrm{ns}}$ & $0.486 * *$ & 1 & $0.875 * *$ & $0.639 * *$ & $0.395 * *$ & $0.108^{\mathrm{ns}}$ & $0.326^{* *}$ & $0.479 * *$ & $0.374 * *$ & $0.189 * *$ \\
\hline Height of back (cm) & $-0.071^{\mathrm{ns}}$ & $0.433 * *$ & $0.875^{* *}$ & 1 & $0.651 * *$ & $0.320 * *$ & $0.097^{\mathrm{ns}}$ & $0.326 * *$ & $0.441 * *$ & $0.417 * *$ & $0.202 * *$ \\
\hline Height of sacrum $(\mathrm{cm})$ & $-0.140 *$ & $0.366^{* *}$ & $0.639 * *$ & $0.651 * *$ & 1 & $0.310 * *$ & $0.109^{\mathrm{ns}}$ & $0.235^{* *}$ & $0.343^{* *}$ & $0.292 * *$ & $0.154 *$ \\
\hline Body length (cm) & $0.059^{\mathrm{ns}}$ & $0.501 * *$ & $0.395 * *$ & $0.320 * *$ & $0.310^{* *}$ & 1 & $0.145^{*}$ & $0.097^{\mathrm{ns}}$ & $0.402 * *$ & $0.239 * *$ & $0.264 * *$ \\
\hline Width of chest (cm) & $0.048^{\mathrm{ns}}$ & $0.277 * *$ & $0.108^{\mathrm{ns}}$ & $0.097^{\mathrm{ns}}$ & $0.109^{\text {ns }}$ & $0.145^{*}$ & 1 & $0.331 * *$ & $0.335^{* *}$ & $0.294 * *$ & $0.364 * *$ \\
\hline Depth of chest $(\mathrm{cm})$ & $0.123^{\mathrm{ns}}$ & $0.413 * *$ & $0.326 * *$ & $0.326^{* *}$ & $0.235^{* *}$ & $0.097^{\mathrm{ns}}$ & $0.331 * *$ & 1 & $0.484 * *$ & $0.364 * *$ & $0.287 * *$ \\
\hline Chest circumference $(\mathrm{cm})$ & $0.164 *$ & $0.811 * *$ & $0.479 * *$ & $0.441 * *$ & $0.343 * *$ & $0.402 * *$ & $0.335^{* *}$ & $0.484 * *$ & 1 & $0.635 * *$ & $0.532 * *$ \\
\hline Width of rump (cm) & $0.082^{\text {ns }}$ & $0.541 * *$ & $0.374 * *$ & $0.417 * *$ & $0.292 * *$ & $0.239 * *$ & $0.294 * *$ & $0.364 * *$ & $0.635^{* *}$ & 1 & $0.619 * *$ \\
\hline Length of rump (cm) & $0.127 *$ & $0.382 * *$ & $0.189 * *$ & $0.202 * *$ & $0.154^{*}$ & $0.264 * *$ & $0.364 * *$ & $0.287 * *$ & $0.532 * *$ & $0.619 * *$ & 1 \\
\hline
\end{tabular}

${ }^{\text {ns }} \mathrm{P}>0.05$ - non significant, $* \mathrm{P}<0.05,{ }^{*} * \mathrm{P}<0.01$

The body length has high correlation with all exterior measures, except with the depth of the chest.

Regarding the strength of the correlation, the general conclusion is that most exterior measures have a relatively weak correlation $(0.2 \leq \mathrm{R}<0.5)$. An average strong correlation $(0.5 \leq \mathrm{R}<0.8)$ was determined between the height of the sacrum and the height of the withers $(0.639)$ and the height of the back (0.651), then between the body length and the body weight $(0.501)$ and other. A very strong correlation $(0.8 \leq \mathrm{R}<1)$ was determined between the height of the withers and the height of the back $(0.875)$ and between the chest circumference and the body weight (0.811).

Analyzing the correlative dependence of the milk yield with the other exterior measures, it has been determined that with most of them it is not correlated, while with a part (the height of the sacrum, the chest circumference and the length of the rump) is in insignificant correlation $(0<\mathrm{R}<0.2)$. Milk yield is in an insignificant correlation with the body weight of the goats. Greater correlation between the lactation and body weight was determined by Iloeje and Van Vleck (1978), which in the Danish goat breed is 0.39 , whereas in the German Improved Fawn goat breed is 0.132 .
During the testing of the two varieties (red and multicolored), Marković (1997) determined the existence of a very strong positive correlation between the length of lactation and the total amount of milk (0.755 and 0.796) in both varieties in the domestic Balkan goat. The same author determined a positive and mainly weak correlation between the traits of milk and body weight, while between the individual body measures there was a positive and statistically significant and strong correlation dependence.

A higher correlation coefficient between body weight and lactation (0.36) was also found by Gall (1980) in his studies of the German Improved Fawn goat breed, as well as Semakula et al. (2010) in local breeds of goats grown in Uganda. Regarding the body weight, it is correlated with almost all exterior measures, but with different strength. For example, with the height of the withers, the height of the back, the height of the sacrum, the width of the chest, the depth of the chest and the length of the rump is in a relatively weak correlation. With the body length and the width of the rump, it is in a medium strong correlation, whereas with the chest circumference is in a strong correlation.

Positive and statistically significant correlation between body weight and certain body measures 
(height of the withers and size of the tibia), in three different genotypes of goats (domestic white goat, F1 crossbreeds between domestic white goat with Saanen goat from Bulgaria and crossbreeds between domestic white goats and Saanen goat from Switzerland), was determined by Žujović et al. (1991, 1993). As in our tests, these authors have determined a strong correlation between body weight and chest circumference in all three genotypes of goats.

Higher correlation dependence ( 0.50 to 0.94 ) was determined between body weight and individual exterior measures in goats of Saanen breed by both Pesmen and Yardimci (2008) and Nemeth et al. (2009) which determined mean and fairly strong $(\mathrm{P} \leq 0.01)$ correlation between body weight and most measures of body development in different breeds of goats grown in Hungary.

\section{CONCLUSION}

Based on the abovementioned tests, the following conclusions can be made:

Considering that it is about a goat population, which is mainly used for milk production, the results obtained for phenotypic correlations between milk yield and individual exterior measures, although weak, the same should be used both by farmers and by breeders to improve milk production.

The possibility of successful selection in relation to the improvement of the milk yield in this breed is also given by the fact that there is a great variation between the minimum and maximum determined individual milk yield in the flock.

Regarding the body weight, in the future selection activities of this breed, attention should be paid to the correlation of this trait with the chest circumference, whose correlation is quite strong not only in our tests, but also in a considerable number of other tests.

\section{REFERENCES}

Gall, C.: Relationship between body conformatiion and production in dairy goats. Journal of Dairy Science, Vol. 63, No. 10, pp. 1768-1781 (1980).

Iloeje, M. U. and Van Vleck, L. D.: Genetics of dairy goats. A review. Jorunal Dairy Sci. 61, 1521-1528 (1978).

Kozarovski, N.. Sheep and Goat Breeding. "St Clement of Ohrid" Unversity in Bitola. 1998, pp. 474,

Latinović, D.: Populaciona genetika i oplemenjivanje domaćih životinja. Praktikum, Beograd. 1996, pp. 150.

Marković, Božidarka: Proizvodne i reproduktivne osobine važnijih varijeteta domaće balkanske koze u Crnoj Gori. Magistarski rad. Poljoprivredni fakultet, Beograd. 1997, pp. 94.

Memisi, N., Bauman, F., Skalicki, Z., Mekić C., Bogdanović. V.: Uticaj stada i laktacije po redu na telesnu razvijenost domaće balkanske koze. $15^{\text {th }}$ Symposium on Innovation in Animal Science and Production. Biotechnology in Animal Husbandry, vol 18, 5-6, pp. 87-94 (2002).

Nemeth, T., Komlosi, I., Molnar, A., Kusza, S., Lengyel, A., Kukovics, S.: Differences between goat breeds based on body measurements in Hungarian populations. Journal Állattenyésztés és Takarmányozás, Vol. 58, No. 4, pp. 353-367 (2009).

Pacinovski, N., Dojchinovski, T., Petrovska, S., Kochoski, Lj., Kozarovski, N., Dumova-Jovanoska, E.: A survey of forming regional reprocentre of sheep and goats in east region. My Ground, Ohrid, 2012, pp. 272.

Semakula, J., Mutetikka, D., Kugomza, R., Donald, V., Mpairwe, D.: Variability in body morphometric measurements and their application in predicting live body weight of Mubende and small East-African Goat breeds in Uganda. Middle-East Journal of Scientific Research 5 (2), 98-105 (2010).

SPSS: SPSS 6.1 for Windows Student Version. Chicago, USA, 1994.

Pesmen, G., Yardimci, M.: Estimating the live weight using some body measurements in Saanen goats. Archiva Zootechnica 11, 4, 30-40 (2008).

Žujović, M., Žujović, Miroslava: Korelaciona povezanost mase tijela i nekih telesnih mera domaće bele koze i njenih meleza sa sanskom kozom. I International Summer Conference for Advancement of Sheep and Goat Production, Ohrid, 10-13 September 1991, pp. 263-268.

Žujović, M., Žujović Miroslava: Fenotipske korelacije izmedju mase tela i nekih telesnih mera u tri genotipa koza, IX Seminar o savremenoj stočarskoj proizvodnji, Novi Sad, 1112 Februar 1993, Savremena poljoprivreda, 1-2,. pp. 128 130 (1993). 
